\title{
Sekularyzacja jako droga do pełnego chrześcijaństwa w świetle koncepcji Gianniego Vattimo
}

\author{
Antoni Torzewski \\ (Uniwersytet Kazimierza Wielkiego w Bydgoszczy, Instytut Filozofii i Socjologii)
}

\section{Wprowadzenie}

Postępująca w dzisiejszym świecie sekularyzacja stanowi impuls do refleksji dla współczesnych filozofów. Kojarzy się ona przede wszystkim ze stosunkiem państwa do religii i jest postrzegana jako nastawienie antyreligijne ${ }^{1}$. Mimo to niektórzy myśliciele starają się ukazać sekularyzację jako, paradoksalnie, drogę do pełni dominującej na zachodzie religii, tj. chrześcijaństwa. Nie wiadomo, na ile jest to jedynie desperacka próba „uratowania” religii przez wierzących w dobie powszechnego odchodzenia od transcendencji, na ile zaś autentyczna i ważka refleksja filozoficzna. Wydaje się jednak, że taka interpretacja sekularyzacji niesie za sobą wiele ciekawych filozoficznie konsekwencji. Skupimy się tu głównie na włoskim filozofie Giannim Vattimo i jego pozytywnej interpretacji sekularyzacji ${ }^{2}$.

Por. Ch. Taylor, J. Maclure, Secularism and Freedom of Conscience, Harvard UP, Cambridge, MA 2011, s. 5. Tłumaczenia cytatów z dzieł podanych w języku angielskim dokonał autor.

2 Pominiemy w tym tekście kwestie biografii Gianniego Vattima. Niektórzy badacze jednak wydają się twierdzić, iż nie sposób wyrazić czy zrozumieć omawianej tu filozofii bez znajomości życiorysu jej autora (por. np. Z. Kobylińska, Gianniego Vattima postulat słabego chrześcijaństwa, „Seminare” 2016, t. 37, nr 3, s. 61-71 albo P. Artemiuk, „Myśl słaba” Gianniego Vattimo a chrześcijaństwo, „Studia nad Rodziną” 2012, nr 16/1-2(30-31), s. 447-468). Nas jednak interesować będzie myśl, nie zaś człowiek, który za nią stoi. 


\section{Sekularyzacja}

Pojęcie sekularyzacji (czy sekularyzmu) jest używane tak często, że jego znaczenie stało się rozmyte i nieostre. Zanim więc przejdziemy do rozważań dotyczących wpływu sekularyzacji na osiągnięcie pełni chrześcijaństwa, musimy zdefiniować, czym ona jest. To, co jawi się w świadomości powszechnej, gdy mówimy „sekularyzacja”, to przede wszystkim postulat separacji państwa od religii - im bardziej państwo jest niezależne od Kościoła, tym bardziej postępuje proces sekularyzacji. To jednak stanowi w istocie tylko część tego, co mają na myśli filozofowie podejmujący refleksję na ten temat, ponieważ sekularyzacja „nie może zostać uchwycona poprzez proste sformułowania takie jak «separacja państwa od Kościoła»" tomiast będzie raczej interesowała intelektualna podstawa tego procesu (pogląd filozoficzny), którą Taylor nazywa „sekularyzmem”.

Sekularyzm można podzielić na dwa typy: 1) polityczny i 2) społeczny:

[...] sekularyzacja polityczna jest procesem, przez który państwo potwierdza swoją niezależność od religii, natomiast jednym z elementów sekularyzacji społecznej jest zanik wpływu religii w praktykach społecznych oraz w konkretnym przeżywaniu. Podczas gdy sekularyzacja polityczna wyraża się $\mathrm{w}$ prawie pozytywnym i polityce społecznej, sekularyzacja społeczna jest fenomenem socjologicznym urzeczywistnionym w konkretnych koncepcjach świata i stylach życia ${ }^{4}$.

Kanadyjski myśliciel na określenie sekularyzmu politycznego używa francuskiego słowa „laicité”, zatem możemy przyjąć, że na gruncie języka polskiego używać będziemy słowa „laicyzm”. Określając cechy laicyzmu, Taylor nie wskazuje bynajmniej jedynie na stosunek państwa do religii. Wyróżnia natomiast dwie kategorie postulatów, które pojawiają się na gruncie laicyzmu: postulat moralny oraz postulaty instytucjonalne ${ }^{5}$. Postulat moralny, będący fundamentem omawianego poglądu, głosi wolność sumienia czy bardziej konkretnie: równość w wolności religijnej. Na nim zaś nadbudowane są postulaty instytucjonalne: 1) separacji państwa od Kościoła i 2) neutralności państwa wobec religii.

Tamże, s. 19.

Tamże, s. 15.

Por. tamże, s. 20. 
Warto wspomnieć, że w zależności od środków, za pomocą których realizuje powyższe postulaty, laicyzm dzieli się na dwa typy: a) liberalno-pluralistyczny i b) republikański ${ }^{6}$. Postulaty laicyzmu zarówno w typie a), jak i w typie b) pozostają takie same. Każdy z nich jednak odnosi się do polityki, nie zaś do społeczeństwa. Dlatego właśnie w Taylorowskiej teorii sekularyzmu występuje wspomniane wyżej odróżnienie sekularyzmu politycznego (laicyzmu) od społecznego. Ten drugi bowiem wyraża pewne społeczne nastawienie, dążenie obecne we współczesności, które charakteryzuje się zanikiem sacrum, transcendencji, a nie wymuszeniem konkretnych działań, których wymagamy od państwa.

Aby lepiej ukazać to rozróżnienie, powołajmy się na teorię konfliktów między społecznością polityczną i religijną, którą możemy znaleźć u Węcławskiego. Wyróżnia on trzy rodzaje konfliktów: 1) na tle kulturowo-religijnym, 2) o porządek władzy i 3) o moralność społeczną7. Pierwszy odnosi się do wypierania jednej religii przez drugą, jest wywołany „przez rozwój nowej religii lub nowej formy religijności w ramach istniejącej już tradycyjnej struktury społecznej”, co jednak nie dotyczy omawianej tu problematyki. Drugi natomiast wyraża Taylorowską ideę laicyzmu. Konflikt o porządek władzy w tym wypadku jest konfliktem między religią a państwem, wywołany zostaje „przez konkurencję hierarchii religijnej i politycznej lub przez rozwój nowych form władzy politycznej w istniejącej już społecznej tradycji życia religijnego"9. Ponieważ zaś żyjemy w XXI wieku, rozgrywa się on pokojowo poprzez sukcesywne wprowadzanie stosownego prawa ${ }^{10}$. Trzeci rodzaj konfliktu opisywanego przez Węcławskiego charakteryzuje to, co Taylor nazywa sekularyzmem społecznym - jest to konflikt między wartościami wyznawanymi przez społeczność religijną i społeczność świecką (którą Węcławski nazywa po prostu społecznością polityczną). Ta druga będzie wymagać porzucenia religijnych wartości, przede wszystkim zaś porzucenia sacrum i transcendencji, proponując w zamian jakieś inne wartości. Taki konflikt wywołany jest „przez rozbieżność między wartościami i ocenami uznawanymi przez tradycyjną społeczność religijną i aktualnie (zazwyczaj zmiennymi) wyob-

Por. tamże, s. 34 .

Por. T. Węcławski, Wspólny świat religii, Znak, Kraków 1995, s. 246.

Tamże, s. 246.

Tamże, s. 247.

10 Mówiąc „pokojowo”, mam na myśli głównie społeczeństwa wysokorozwinięte. Przykładem zaś konfliktu rozwiązywanego niepokojowo może być spór papieża Grzegorza VII z cesarzem Henrykiem IV. 
rażeniami o «dobru społecznym» określającymi polityczne działania grupy nią rządzącej"11. Kategorie ukazane przez polskiego filozofa dobrze obrazują Taylorowski podział na laicyzm i sekularyzm społeczny.

Kanadyjski myśliciel nie prezentuje jednak koncepcji, na gruncie której laicyzm czy sekularyzm miałby jednoznacznie prowadzić do pełni chrześcijaństwa. Nie jest również skłonny oceniać tych zjawiska wprost pozytywnie, choć wydaje się, że przychyla się do liberalno-pluralistycznej wersji laicyzmu, zarazem krytykując sekularyzację, ponieważ „państwo musi dążyć do bycia politycznie zsekularyzowanym, lecz nie promować sekularyzacji społecznej"12. Bardziej przejrzystą pod tym względem koncepcję prezentuje natomiast Gianni Vattimo.

Gdzie jednak należałoby umieścić głoszoną przez niego sekularyzację, biorąc pod uwagę omówione wyżej kategorie Taylora i Węcławskiego? Włoski filozof definiuje sekularyzację jako „proces «dryfowania», który odsunął nowoczesną laicką cywilizację od jej sakralnych początków”"13. Wydaje się, że należy rozumieć te słowa w kontekście przede wszystkim społecznym. Szczególnie, że Vattimo wskazuje także na „inne” rozumienia sekularyzacji, które jednak nie wyrażają dokładnie jego poglądu:

[...] można również mówić o współczesności jako sekularyzacji w innych sensach, które jednak wciąż są powiązane $\mathrm{z}$ ideą desakralizacji agresywnego [violent], autorytatywnego i absolutnego sacrum religii naturalnej: na przykład, zmiana władzy państwowej, z nadanej przez bóstwo do ustanowionej konstytucyjnie monarchii, czy aż do demokracji pośredniej, może być równie dobrze (jeśli nie wyłącznie) opisana w ramach sekularyzacji ${ }^{14}$.

Sekularyzacja zatem, w myśli Vattimo, stanowi proces przede wszystkim społecznych przemian prowadzących do desakralizacji świata ${ }^{15}$. Używając Taylorowskiej kategorii, Vattimo rozważa sekularyzm społeczny, nie zaś polityczny, omawia konflikt na tle moralności społecznej (jak nazwałby to Węcławski), który toczy się między współczesnymi laikami dążącymi do desakralizacji i wprowa-

\footnotetext{
Tamże, s. 248.

Ch. Taylor, J. Maclure, dz. cyt., s. 16.

G. Vattimo, Belief, Stanford UP, Stanford 1999, s. 41.

Tamże, s. 42.

15 Ciekawym zagadnieniem jest, na ile źródłem sekularyzmu jest współczesny skrajny antropocentryzm i indywidualizm. Nie tylko bowiem religia traci swoje znaczenie na gruncie współczesności, lecz także wszystko, co związane z jakimś rodzajem transcendencji i sacrum.
} 
dzenia „wartości antropocentrycznych” (takich jak konkretnie pojęta równość, wolność, solidarność wywiedzione $\mathrm{z}$ areligijnych podstaw) a wierzącymi, którzy potrafią jeszcze dostrzec transcendencję i w związku z tym postulują „wartości boskie" (takie jak pobożność czy miłość bliźniego oparte na fundamentach religijnych).

Czy jednak faktycznie tak przedstawia się filozofia Vattima? W kolejnej części tekstu skupimy się na tym konflikcie wartości oraz postaramy się ukazać, jak interpretuje go włoski myśliciel. Należy jednak wpierw przedstawić jeszcze dwa inne konteksty związane z jego rozważaniami nad sekularyzacją, aby pełniej zrozumieć jego myśl oraz aby móc odnieść jego koncepcję sekularyzacji do omawianej w tym artykule tezy, że prowadzi ona do pełni chrześcijaństwa.

Filozofia Gianniego Vattima jest nazywana „myślą słabą” [pensiero debole] (bądź stanowi jej część), która nie jest „ideą myślenia, które jest bardziej świadome własnych granic, które porzuca roszczenia do oglądu całościowego i metafizycznego, ale przede wszystkim jest teorią osłabiania jako konstytutywnego charakteru Bycia w epoce końca metafizyki”"16. Również prezentowana przez Vattima teoria sekularyzacji wpisuje się w ten kontekst. „Myśl słaba” skupia się przede wszystkim na "przezwyciężeniu metafizyki” (w sensie Verwindung) osłabieniu mocnych struktur Bytu. Zamiast „klasycznej” metafizyki propagatorzy „myśli słabej” proponują, za Heideggerem, ontologię Bytu, który się wydarza, który jest historyczny czy dziejowy. Jako taki zaś, Byt nie jest niezmienny i jeden, lecz nieustannie ewoluuje, zmienia się, dlatego nie można głosić o nim, że jest jakiś i zawsze taki będzie, np. nie głoszą przedstawiciele „myśli słabej”, że człowiek ma jakąś naturę, która jest mu wewnętrzna oraz określona. „Przezwyciężenie metafizyki” prowadzi z jednej strony do tezy ontologicznej - że „bycie nie «jest», ale «staje się» $[. .$.$] ontologia nie jest niczym innym jak interpretacją naszej kon-$ dycji i sytuacji, jako że bycie spełnia się w całości w swoim «wydarzeniu», następującym w procesie jego i naszego stawania się historią"17 $-\mathrm{z}$ drugiej natomiast do stanowiska epistemologicznego - że prawda obiektywna albo jest niepoznawalna, albo wręcz nie istnieje, ponieważ „prawda, owo otwarcie, w którym świat każdorazowo jawi się historycznym społecznościom, jest wydarzeniem, a nie stabilną strukturą"18. Zabala, określając tę myśl, pisze:

\footnotetext{
$16 \quad$ Tamże, s. 35.

17 G. Vattimo, Koniec nowoczesności, tłum. M. Surma-Gawłowska, Universitas, Kraków 2006, s. 3.

18 Tamże, s. 68.
} 
[] myśl postmetafizyczna ma na celu przede wszystkim ontologię osłabiania, która redukuje wagę obiektywnych struktur i przemoc dogmatyzmu [...]. [F]ilozofia nie ukazuje jakiejś prawdy, ale jedynie sprzyja możliwości konsensusu, który może być postrzegany jako prawda ${ }^{19}$.

Nacisk na dziejowość ontologiczną i relatywizm poznawczy przejawia się także konkretnie w rozważaniach nad religią i sekularyzacją. „Śmierć Boga” wyrażona $\mathrm{w}$ dziele Nietzschego ${ }^{20}$ jest dla przedstawicieli „myśli słabej” śmiercią Boga metafizycznego: „wiara w Boga nie jest już potrzebna ani nawet «moralnie» możliwa - przynajmniej wiara w Boga tradycji onto-teologicznej”21. „Śmierć Boga” jest zerwaniem w myśleniu z Bogiem pojętym scholastycznie, z Bogiem, o którym można orzekać (niezależnie, czy via negativa, czy via positiva), wreszcie z Bogiem, który jest (w odróżnieniu od Boga, który się wydarza). Świat po śmierci Boga to świat, w którym „metanarracje zostały oddalone a każdy autorytet na szczęście zdemitologizowany, włączając w to autorytet "obiektywnej wiedzy»"22. W sekularyzacji natomiast widzą oni wyraz „myśli słabej”, jako że sekularyzacja to wydarzenie połączone $\mathrm{z}$ „koncepcją historii współczesności jako osłabianiem i rozpadaniem się (metafizycznego) Bytu"23. Założenie o niepoznawalności albo braku prawdy obiektywnej ze względu na dziejowość Bytu prowadzi do interpretacji sekularyzacji jako pozytywnego efektu ${ }^{24}$, który demaskuje „mocne struktury”, poprzez desakralizację bowiem odziera się Boga z jego absolutności, a więc odziera się z niej także religię jako taką. „ "Odczarowanie» - pisze Vattimo - to rozpoznanie, że nie istnieja obiektywne struktury, wartości, prawa, że wszystko jest ludzkim ustanowieniem i kreacją"25. Oczywiście stanowi to pewnego rodzaju kryzys autorytetu, ponieważ przed sekularyzacją istniała instancja, do której zawsze można było się odwołać, która zawsze dostarczała ostatecznych odpowie-

19 S. Zabala, A Religion Without Theists or Atheists, w: R. Rorty, G. Vattimo, The Future of Religion, ed. by S. Zabala, Columbia UP, New York 2005, s. 9.

20 Por. F. Nietzsche, Wiedza radosna, tłum. L. Staff, Warszawa 1906, s. 125.

21 G. Vattimo, Poza interpretacją, tłum. K. Kasia, Kraków 2011, s. 121. Por. także, tenże, Koniec nowoczesności, dz. cyt., s. 20.

22 R. Rorty, G. Vattimo, dz. cyt, s. 54.

23 G. Vattimo, Belief, dz. cyt., s. 41.

24 Jak pisze Vattimo: „Sekularyzacja stanowi [...] istotny aspekt historii zbawienia”. G. Vattimo, After onto-theology: philosophy between science and religion, w: Religion after Metaphysics, ed. M. Wrathall, Cambridge UP, Cambridge 2003, s. 35.

25 G. Vattimo, Społeczeństwo przejrzyste, tłum. M. Kamińska, Wydawnictwo Naukowe Dolnośląskiej Szkoły Wyższej Edukacji, Wrocław 2006, s. 104. 
dzi i wyznaczała arbitralne granice. W dobie sekularyzacji natomiast instancja taka już nie istnieje. Patrząc na to w szerszym kontekście, sekularyzacja realizuje dokładnie te same dążenia, co „myśl słaba” (oraz nihilistycznie pojęta hermeneutyka), która również chce osłabić autorytet i ukazać, że prawda obiektywna jest złudzeniem (albo że nie da się do niej dojść, co w pewnym kontekście znaczy prawie to $\left.\mathrm{samo}^{26}\right)$. Co więcej „cechą kenosis, w którym realizowana jest historia zbawienia, musi być całe to doświadczenie [...] osłabiania mocnych struktur"27, a więc właśnie sekularyzacja.

Sekularyzacja w teorii Vattima wiąże się również z myślą Renego Girarda dotyczącą relacji sacrum i przemocy ${ }^{28}$. Włoski myśliciel podaje interpretację, zgodnie z którą to, co święte, ma ścisły związek z przemocą i to przemocą pojętą jako „przemoc metafizyczna”. „Naturalna świętość jest przemocą nie tylko dlatego, że mechanizm ofiary zakłada spragnioną zemsty boskość, ale również dlatego, że przypisuje tej boskości atrybuty wszechmocy, doskonałości, wieczności i «transcendencji» w stosunku do ludzkości"29 - pisze Vattimo. Bóg (Byt), który jest, jest prawdą obiektywną, można o nim konkretnie mówić (dochodzić do prawdy), a to, co mówimy, ukazuje jego potęgę. Bóg jest istotą absolutną, wszechmocną, wszechwiedzącą, wieczną itd. W jego obliczu wszystko inne jest marnością, a to, co on nakazuje, jest absolutnie prawomocne. Taki Bóg jawi się w tradycji żydowskiej - jest tak wielką mocą, że lepiej się do niego nie zbliżać. Nie dlatego, że jest zawistny albo że lubuje się w przemocy, ale dlatego, że jest jak człowiek, który chodzi drogą pełną mrówek; nie ma wobec nich złych intencji, ale jego moc jest tak wielka, że może doprowadzić do ich śmierci „przez przypadek”30.

Dlatego właśnie Bóg nigdy nie ukazuje się człowiekowi bezpośrednio, lecz zawsze pośrednio, np. za pomocą gorejącego krzewu. Moc Boga wypływa właśnie $\mathrm{z}$ tego, konkretnego metafizycznego rozumienia. Zatem człowiek żyjący z takim pojęciem Boga jest $\mathrm{w}$ pewnym sensie poddany przemocy $\mathrm{z}$ jego strony, przemo-

26 Vattimo uważa, że prawda nigdy nie będzie obiektywna, dotyka bowiem tylko pewnego wycinka rzeczywistości: „każde stwierdzenie może zostać zweryfikowane lub sfalsyfikowane jedynie w obrębie jakiegoś horyzontu (otwarcia, paradygmatu, języka), który z kolei sam nie może być zweryfikowany". G. Vattimo, After onto-theology..., dz. cyt., s. 34.

27 Tenże, Belief, dz. cyt., s. 52.

28 Por. Girard, R., Sacrum i przemoc, tłum. M. Plecińska, Wydawnictwo Brama, Poznań 1993.

29 G. Vattimo, Belief, dz. cyt., s. 39.

30 Por. P. Cary, Philosophy and Religion in the West, The Teaching Company, wykład szósty, 1993. Istnieje także pogląd, że Bóg w istocie jest zawistny, żądny zemsty. Wtedy tym bardziej jego moc byłaby przemocą wobec człowieka. 
cy metafizycznej. Można także twierdzić, że takie rozumienie Boga jest źródłem faktycznej przemocy, tj. konfliktów czy wojen prowadzonych na tle religijnym, ponieważ myślenie o Bogu w kategoriach mocy, prawdy czy absolutu sprawia, że wszystko inne, co związane z religią, również pojmowane jest poprzez te pojęcia. Sekularyzacja natomiast służy właśnie temu, aby zerwać z takim pojmowaniem istoty najwyższej i tym samym zerwać z przemocą - zarówno metafizyczną, jak i immanentną światu. „To właśnie Jezus uwidacznia, że świętość jest przemocą, i rozpoczyna w ten sposób nową historię ludzkości" ${ }^{31}$. Umożliwia to oczywiście omówione wyżej „przezwyciężenie metafizyki” prowadzące do zniesienia Boga jako najwyżej instancji i autorytetu - „rozpad metafizyki stanowi również koniec takiego obrazu Boga, śmierć Boga, o której mówił Nietzsche"32. Należy zatem na gruncie sekularyzacji zreinterpretować pojęcie Boga w kategoriach niemetafizycznych, a możliwe jest to dzięki odwołaniu się do postaci Jezusa. W tym miejscu bardzo ważna staje się, używana przez Vattima, kategoria kenosis - uniżenia. Jak bowiem mielibyśmy mówić o Bogu jako transcendencji, nie używając pojęć metafizyki? Aby wyjść $\mathrm{z}$ tego impasu, należy stwierdzić, że Bóg pozbawia sam siebie własnej transcendencji, uniża się jako Jezus i pojawia się w ludzkim świecie, tym samym czyniąc się bytem dziejowym. Wtedy nie jest on „ani prawdą, ani mocą, lecz tylko miłością" ${ }^{33}$. Natomiast z perspektywy klasycznej metafizyki „jedynym wielkim paradoksem i skandalem chrześcijańskiego objawienia jest [właśnie] wcielenie Boga, kenosis - pozbawienie wszelkich transcendentnych, niepojętnych, tajemniczych czy wręcz dziwacznych cech [...]"34. Co więcej, kenotyczny Bóg-Jezus poprzez swoje przyjście ukazuje „tajemnicę” religii, którą stanowi interpretacja.

Sekularyzacja w myśli Vattima sytuuje się zatem w obrębie sekularyzmu społecznego (nie zaś politycznego), ukazuje konflikt na tle moralności społecznej (nie jest to natomiast konflikt na tle walki o władzę) i obejmuje co najmniej dwie perspektywy, z których należy na nią patrzeć - z jednej strony sekularyzacja jest wyrazem dążenia „myśli słabej” do przezwyciężenia metafizyki, z drugiej zaś stanowi próbę neutralizacji przemocy. Jednak włoski myśliciel pojmuje sekularyzację również na poziomie znacznie głębszym, utożsamia bowiem z se-

\footnotetext{
G. Vattimo, Społeczeństwo przejrzyste, dz. cyt., s. 52.

Tenże, Belief, dz. cyt., s. 39.

R. Rorty, G. Vattimo, dz. cyt., s. 36.

G. Vattimo, Belief, dz. cyt., s. 55.
} 
kularyzmem samo chrześcijaństwo ${ }^{35}$ - posługuje się w tym celu wspomnianą już kategorią kenosis odniesioną do Jezusa. Rudolf Otto, charakteryzując Świętość, zwraca uwagę na trzy jej aspekty: tremendum, numinosum i fascinans ${ }^{36}$. Bóg metafizyczny zawiera je wszystkie, Jezus natomiast dzięki uniżeniu pozostawia za sobą element tremendum i numinosum. Jedyne, co zostaje, to fascinans, o czym świadczyć może fragment: „I rzekł do nich: «Pójdźcie za Mną, a uczynię was rybakami ludzi». Oni natychmiast zostawili sieci i poszli za Nim"37 - Piotr i Andrzej ulegli elementowi fascinans w Jezusie, nieodpartej „mocy przyciągania”, która z niego emanowała. Jezus był dla nich „czymś szczególnie pociągającym, czarującym, fascynującym"38. Natomiast pozostałe dwa elementy są już nieobecne. To ukazuje, że Jezus nie jest już tym Świętym, tym absolutnym Bogiem metafizyki, lecz kimś nowym, bardziej ludzkim, pozbawionym transcendencji. Wraz z przyjściem Jezusa zmienia się także relacja człowieka do Boga, ponieważ „nie powinniśmy już myśleć o sobie jako o sługach bożych, ale jego przyjaciołach”39. Czymże innym zaś jest takie pozbawianie transcendencji niż sekularyzacją?

To właśnie centralna postać chrześcijaństwa, postać Jezusa, wskazuje na sekularny charakter całego chrześcijaństwa jako rezygnacji z transcendencji, osłabiania mocnych struktur. „Jezus Chrystus przybył, aby zapomnieć, a nie żeby dopełnić świętość i potrzebę ofiary. Jezus jest pierwszym, wielkim desakralizatorem religii naturalnych. Przybywa i pokazuje wszystkim, że to nieprawda, iż Bogu należy składać ofiary. A nawet, że Bóg nazywa nas przyjaciółmi” ${ }^{\prime 40}$. Desakralizacja odnosi się również nie tylko wewnętrznie do chrześcijaństwa - chrześcijaństwo nie tylko sekularyzuje samo siebie, lecz także jest sekularyzacją wobec innych, wcześniejszych religii np. judaizmu czy różnego rodzaju politeizmów (tego wszystkiego, co Vattimo nazywa „religią naturalną”). Bazując na swej teorii chrześcijaństwa jako sekularyzacji, Vattimo mógłby wysnuć zarzut wobec scho-

35 W swej autobiografii Vattimo pisze, że Rene Girard „jest człowiekiem, dzięki któremu zacząłem myśleć, że istnieje możliwość połączenia osłabienia, sekularyzacji i chrześcijaństwa”. G. Vattimo, P. Paterlini, Nie być Bogiem. Autobiografia na cztery ręce, tłum. K. Kasia, Wydawnictwo Krytyki Politycznej, Warszawa 2011, s. 135. Rozważania nad myślą francuskiego filozofa doprowadziły go w końcu do utożsamienia chrześcijaństwa z sekularyzacją, o czym świadczy wykład pod tytułem Christianity as Secularization.

36 Por. R. Otto, Świętość, tłum. B. Kupis, Thesaurus Press, Wrocław 1993.

37 Mt 4, 19.

38 R. Otto, dz. cyt., s. 59.

39 G. Vattimo, Belief, dz. cyt., s. 55.

40 G. Vattimo, P. Paterlini, Nie być Bogiem..., dz. cyt., s. 136. 
lastyki, że opacznie zrozumiała przekaz Jezusa i zamiast zgodzić się na sekularyzację, również jego włączyła w ramy metafizyki, co jednak przeczyłoby temu, że chrześcijaństwo jako takie jest sekularyzacją.

Można także spróbować przenieść teorię Vattima z płaszczyzny społecznej na polityczną i zbadać, czy również w tym wymiarze sekularyzacja będzie prowadziła do pełni chrześcijaństwa. Tym jednak zajmiemy się w dalszej części tekstu, wpierw bowiem należy ukazać, czym dla Vattima jest owa pełnia chrześcijaństwa - jaka jest jego istota? Jaką rolę pełni w nim Bóg? Jak należy rozumieć współczesne zsekularyzowane chrześcijaństwo?

\section{Pełnia chrześcijaństwa}

Centralnym pojęciem chrześcijaństwa wedle Vattima jest kategoria miłosierdzia (albo miłości). Podobnie do przedstawicieli religii moralnej ${ }^{41}$ włoski myśliciel sprowadza omawianą religię głównie do wartości, które niesie, oraz do moralności, która z nich wypływa:

[...] istota zbawienia zostaje zredukowana do miłosierdzia, wszystko inne natomiast związane jest z nie-ostatecznością różnorodnych doświadczeń historycznych, wręcz mitologii, które w danym czasie wydawały się być 'wiążącymi' dla konkretnych historycznych społeczności ${ }^{42}$.

Przykazanie miłości, które objawia Jezus, jest istotą chrześcijaństwa i wedle niego jedynie należy postępować. Wszystko inne jest tylko „naleciałością” historyczną, w religii bowiem liczy się mój stosunek do drugiego oraz naśladowanie Jezusa, które wyraża się w działaniu podług przykazania miłości. Natomiast wypełnianie praktyk religijnych, takich jak uczęszczanie na mszę świętą czy przyjmowanie komunii itd., nie stanowi ważnej wewnętrznej cechy religii chrześcijańskiej, jest to jedynie pewnego rodzaju nadbudowa, która może stanowić coś

\footnotetext{
$41 \quad$ Mam tu na myśli np. Kanta, Lessinga, Hegla czy Fichtego. Można zauważyć ciekawe paralele między teorią Vattima a koncepcją religii moralnej, nawet do takiego stopnia, by uznać tego pierwszego za pewnego rodzaju kontynuatora myśli filozofów nowożytnych (oczywiście w pewnych wąskich aspektach, istnieje bowiem wiele kwestii podstawowych i ogólnych, co do których Vattimo nie zgodziłby się z wspomnianymi filozofami).

G. Vattimo, Belief, dz. cyt., s. 77.
} 
istotnego jedynie dla „religijnie muzykalnych"43 ludzi. Inni natomiast, tacy jak sam Vattimo, wyznają:

[...] powracam do kościoła jedynie przy smutnych lub formalnych okazjach [...]: na pogrzeby ludzi, którzy byli mi drodzy, albo na ich chrzty czy śluby. Kilka razy, i to z powodów czysto estetycznych [...], byłem na śpiewanej łacińskiej liturgii Bożego Narodzenia w jedynym z niewielu kościołów, które jeszcze to praktykują ${ }^{44}$.

Jeśli zaś kult i obrządek religijny, którego celem jest oddawanie czci Bogu ${ }^{45}$, zostaje zmarginalizowany (albo sprowadzony tylko do estetyki), to warto zapytać: jaki jest status Boga w tym, nowym, chrześcijaństwie? Vattimo wydaje się przyjmować w tej kwestii postawę sceptyczną, nie chce nic sądzić o Bogu i umieszcza go poza sferą epistemologiczną. Zabala, charakteryzując myśl włoskiego filozofa, pisze, iż dochodzi on do wniosku, że „pytania o naturę Boga są bezużyteczne z powodu słabości naszego rozumu"46. Mamy tu na myśli oczywiście Boga niemetafizycznego, zsekularyzowanego, tj. Boga pozbawionego Ottowskich elementów tremendum i numinosum.

Bóg metafizyczny bowiem dla włoskiego filozofa (który podąża tu za Nietzschem) jest bogiem umarłym ${ }^{47}$. Przy takim rozumieniu tworzy się pewien paradoks, ponieważ Bóg traci swoją ważność i wartość w stanowisku teistycznym - rodzi się teizm bez Boga, który zasadniczo teizmem już nie może być nazywany. Vattimo jednak zdaje sobie z tego sprawę - nazywa siebie katolikiem ateistą. Włoski myśliciel nie traktuje bowiem chrześcijaństwa jako teizmu, ale raczej jako pewien zbiór wartości niekoniecznie ukonstytuowanych na transcendentnych podstawach, w którym Bóg nie odgrywa zbyt dużej roli (ewentualnie jako uniżony Bóg-Jezus). W ponowoczesności „chrześcijaństwo umożliwiło eksplikację swego całkowicie antymetafizycznego efektu a «rzeczywistość» we wszystkich jej aspektach została zredukowana do przesłania"48.

43 Vattimo używa tego pojęcia jako przeciwstawnego do kategorii Webera - „religijnie niemuzykalny".

44 G. Vattimo, Belief, dz. cyt., s. 69.

45 Oczywiście można tu wskazać również inne cele, takie jak np. zacieśnianie więzi wspólnoty Kościoła. Nie o to jednak będzie chodzić włoskiemu myślicielowi.

46 S. Zabala, dz. cyt., s. 11.

${ }_{47}$ Por. G. Vattimo, Ślad śladu, tłum. E. Łukaszyk, w: J. Derrida, G. Vattimo, Religia, Wydawnictwo KR, Warszawa 1999, s. 103.

48 R. Rorty, G. Vattimo, dz. cyt., s. 49. 
Przykładem, który dobrze ilustruje taką wizję religii, jest praca misjonarzy, którzy jadąc „ewangelizować” ludy prymitywne, w pierwszej kolejności nie mówią o tym, że Bóg jest w trzech osobach, że Maryja została wniebowzięta itd., ale raczej budują szpitale, szkoły, starają się polepszyć warunki bytowe ludzi, których spotykają. Kierują się bowiem przykazaniem miłości i dzięki temu, że okazują miłość innym, przybliżają ich do wiary chrześcijańskiej. Nie dzieje się tak zaś dlatego, że na misjach poświęcają większość czasu, który posiadają, edukacji chrześcijańskiej tubylców ${ }^{49}$. Słowo „ewangelizacja” podaliśmy w cudzysłowie właśnie dlatego, że trudno już dziś mówić o ewangelizacji, praca misjonarzy nie skupia się bowiem na zapoznaniu innych ludzi z ewangelią, ale poprzez „praktyczną" naukę wiary w postaci przyczyniania się do polepszenia życia tych ludzi i nadanie sensu ich egzystencji ukazuje religię chrześcijańską.

Dzisiejsza wiara chrześcijańska, wedle Vattima, to już nie autorytarne rządy metafizycznego Boga mocy, ale społeczność ludzi kochających się nawzajem i chętnych udzielać sobie pomocy zgodnie z przykazaniem miłości. „Jedyną prawdą, którą odkrywa przed nami Biblia, jest praktyczne wezwanie do miłości, do miłosierdzia. Prawdą chrześcijaństwa jest rozpad samej metafizycznej koncepcji prawdy. Chrześcijaństwo bez Boga reprezentuje wiarę wolną od obiektywistycznej metafizyki, która wierzyła we własną możliwość wykazania [...] istnienia Najwyższej Istoty" ${ }^{\prime 0}$ - pisze Zabala o religii wedle Vattima.

Włoski myśliciel wskazuje także na interpretacyjny charakter chrześcijaństwa. Jezus bowiem swoim nauczaniem i życiem nie robił nic innego, jak właśnie interpretował zastaną religię judaistyczną. Jak pisze Vattimo:

Objawienie nie mówi o prawdzie obiektywnej, lecz o wciąż trwającym zbawieniu. Co więcej, może to być widoczne już w relacji, jaką Jezus ustanowił między sobą a prorokami Starego Testamentu: ukazuje siebie jako autentyczną interpretację proroctw, chociaż przed opuszczeniem swoich wyznawców obiecuje, że ześle na nich Ducha Prawdy, który będzie kontynuował nauki i zarazem również historię zbawienia przez reinterpretowanie również doktryn samego Jezusa ${ }^{51}$.

\footnotetext{
49 Por. G. Vattimo, Christianity as Secularization, URL: https://www.youtube.com/watch? $\mathrm{v}=\mathrm{qK} 3 Z s v P S L Z I \& \mathrm{t}=4374 \mathrm{~s}$, dostęp: 20.04.2020.

50 R. Rorty, G. Vattimo, dz. cyt., s. 14.

51 G. Vattimo, Belief, dz. cyt., s. 48.
} 
Jezus wskazał na inne, bardziej metaforyczne i głębsze, rozumienie Starego Testamentu, a także ukazał klucz interpretacyjny w postaci przykazania miłości. Wedle tej miłości działał, żył oraz rozumiał otaczający go świat. Naśladowaniem Jezusa zatem, dla współczesnych chrześcijan, będzie interpretacja Biblii w sposób ukazujący jej znaczenie dla konkretnego człowieka, dziś, w epoce, w której żyje. Jedyną granicą tej interpretacji (i zarazem sekularyzacji, demitologizacji) jest przykazanie miłości albo słowa Augustyna „kochaj i rób, co chcesz”. „Jedyną prawdą, którą objawia nam Pismo, prawdą, która nie może zostać zdemitologizowana - ponieważ nie jest ona twierdzeniem eksperymentalnym, logicznym czy metafizycznym, lecz praktycznym wezwaniem - jest prawda miłości, miłosierdzia" ${ }^{2}$. Vattimo także zbawienie widzi w kontekście demitologizacji (która kończy się na miłości), ponieważ zdaje sobie sprawę, że:

[...] sam Chrystus jest demaskatorem, i że zapoczątkowana przez niego demaskacja [...] jest znaczeniem samej historii zbawienia. Zatem wierzyć w zbawienie nie będzie znaczyło trzymać się wszystkiego, co napisane w Ewangelii i zawarte w dogmatycznych naukach Kościoła, lecz raczej próbować znaleźć znaczenie tekstu ewangelicznego dla mnie, tu i teraz ${ }^{53}$.

Historia zbawienia to historia postępującej sekularyzacji, postępującego demitologizowania świata, samo zaś zbawienie zostaje zredukowane do miłosierdzia (miłości), jest wyzbyciem się przemocy rozumianej zarówno jako przemoc metafizyczna, jak i jako przemoc faktyczna, taka jak wojny na tle religijnym. Wierzyć w zbawienie zatem to wierzyć $\mathrm{w}$ interpretację Biblii dostosowaną do potrzeb konkretnego człowieka w konkretnym czasie i miejscu, nie zapominając przy tym o miłości bliźniego. Na gruncie omawianej filozofii religii objawienie ma charakter dziejowy. Mogłoby to stanowić ciekawą bazę do obrony aktualności przesłania Biblii i zawartej w niej prawdy obiektywnej. Częstym zarzutem bowiem jest właśnie dystans czasowy, który dzieli napisanie Świętej Księgi i życie Jezusa od współczesności. Krytycy twierdzą, że prawdy tam zawarte straciły już swoją ważność ze względu na czasy, w których zostały sformułowane. Przyjmując jednak, że Biblię należy rozumieć w kontekście historycznym, przyjmujemy także, że należy ją interpretować w zależności od czasu i epoki. Taka obrona jednak nie jest możliwa na gruncie filozofii Vattima, ponieważ neguje on pojęcie prawdy obiektywnej.

52 R. Rorty, G. Vattimo, dz. cyt., s. $50-51$
53 G. Vattimo, Belief, dz. cyt., s. 66. 


\section{Sekularyzacja jako droga do pełni chrześcijaństwa}

Włoski filozof uznaje, że dopiero dzięki sekularyzacji możliwe jest pełne chrześcijaństwo, tj. chrześcijaństwo oparte na przykazaniu miłości. Sekularyzacja bowiem, jak powiedzieliśmy wcześniej, osłabia mocne struktury, prowadzi do zerwania z przemocą oraz niszczy autorytet i metafizycznego Boga. Jak pisze Vattimo:

Sekularyzacja jako fakt „pozytywny” podkreślający rozpad sakralnych struktur społecznych, przejście do etyki autonomii, do laickiego państwa, do bardziej swobodnego podejścia w interpretowaniu dogmatów i przykazań, powinna być rozpatrywana nie jako porażka czy odejście od chrześcijaństwa, lecz jako pełniejsze realizowanie jego prawdy, którą jest, jak pamiętamy, kenosis, uniżenie się Boga, które osłabia „naturalne” cechy bóstwa ${ }^{54}$.

Coraz bardziej zatem proces sekularyzacji umożliwia wyłonienie się chrześcijaństwa, w którym nie liczą się dogmaty dotyczące natury Boga albo jego autorytarne rządy, lecz sformułowane przez Jezusa przykazanie miłości oraz dokonana przez niego interpretacja Biblii - wskazanie na dziejowy charakter nie tylko Świętej Księgi, lecz także samego Boga. Udocześnienie religii wydarzające się za sprawą sekularyzacji kieruje wzrok ku doczesności i moralności, ku drugiemu człowiekowi. Ważne staje się zagadnienie, jak być konkretnym chrześcijaninem tu i teraz. Jest to problem stawiany np. przez Taylora w pracy A Catholic Modernity, w której pisze:

[...] nie chodzi o to, aby być „współczesnym katolikiem”, jeśli przez to zaczynamy postrzegać się (być może nie w pełni świadomie i tajemniczo) jako ostatecznych „absolutnych katolików” podsumowujących i wykraczających poza naszych mniej uprzywilejowanych przodków [...]. Chodzi raczej o to, aby rozumieć naszą współczesną cywilizację jako kolejną z tych wielkich form kultury, które przychodziły i odchodziły poprzez ludzką historię, aby zobaczyć, co to znaczy być chrześcijaninem tutaj, aby znaleźć nasz autentyczny głos w możliwym katolickim chórze $[\ldots]^{55}$.

\footnotetext{
$54 \quad$ Tamże, s. 47.

55 Ch. Taylor, A Catholic Modernity, dz. cyt., s. 15.
} 
Zwraca on jednak uwagę na to, że nie należy myśleć o dzisiejszym chrześcijaństwie jako „lepszym”, „ostatecznym” czy „urzeczywistnionym”, co natomiast wydaje się twierdzić Vattimo. Oczywiście włoski myśliciel nie użyłby słowa „lepsze”, ponieważ to zakładałoby, że znany nam jest jakiś konkretny stan idealny, do którego mielibyśmy się przybliżać. Zamiast tego mówi o „pełnym” chrześcijaństwie, co jednak narzuca pewnego rodzaju aksjologiczny wydźwięk, ponieważ „pełne” jest raczej lepsze niż „niepełne”. Szczególnie w odniesieniu do chrześcijaństwa.

Vattimo zakłada, że proponowana przez niego interpretacja chrześcijaństwa bardziej oddaje jego „sedno” niż interpretacje np. metafizyczne. Mimo to kwestia bycia chrześcijaninem tu i teraz pozostaje ważna zarówno dla włoskiego myśliciela, jak i dla Taylora. Wydaje się, że jest to wyraz uznania historycznego charakteru religii (przy czym przypuszczalnie Taylor nie uznałby również Boga tylko za wydarzającego się, tak jak czyni to Vattimo). Charakter ten natomiast ukazywany jest właśnie między innymi przez sekularyzację. Jeśli bowiem uznamy sekularyzację za proces - a tak ją rozumie Vattimo - i stwierdzimy również, że chrześcijaństwo jako takie jest właśnie tym procesem, to musimy wysnuć wniosek, że chrześcijaństwo jest historyczne. Kwestia historycznego Boga natomiast nie wypływa już wprost z sekularyzacji, dlatego możliwa jest sytuacja, w której Vattimo uznaje Boga za dziejowego, a Taylor niekoniecznie.

Włoski myśliciel zwraca jeszcze uwagę na kwestię moralności chrześcijańskiej i jej związku z sekularyzacją. Powstaje bowiem zagrożenie, że wraz ze śmiercią Boga metafizycznego i osłabianiem mocnych struktur, rozpadnie się również moralność, która wydaje się mieć swe podstawy właśnie w tych mocnych strukturach i tym, metafizycznym Bogu. Cóż by wtedy pozostało z religii? Dla Vattima wartości i moralność chrześcijańska odgrywają kluczową rolę, są istotnym aspektem religii, dlatego stara się on znaleźć rozwiązanie tego problemu w świetle pozytywnie rozumianej sekularyzacji. Moralność chrześcijańska nie musi być (czy wręcz nie jest) obiektem sekularyzacji, ponieważ proces ten dotyczy jedynie jej podstaw, nie zaś jej samej. Podstawy te w istocie rozpadają się, moralność mimo to pozostaje. Ma teraz jednak inne fundamenty. Nawoływania do przestrzegania moralności proponowanej przez Kościół nie są już konstytuowane na niezmiennych dogmatach czy naturze Boga, ale stanowią dla wierzących pewnego rodzaju wyzwanie. Wymaga się bowiem od nich czegoś więcej. Vattimo posługuje się przykładem moralności seksualnej - do ujemnej wartości 
moralnej czynu takiego jak masturbacja nie dochodzi się poprzez porównywanie jej do ludobójstwa (jak to miało czasem miejsce wcześniej), ale poprzez wizerunek „prawdziwego wierzącego”. Podobnie nakazy i zakazy związane $\mathrm{z}$ rodziną, stosunkiem przedmałżeńskim czy używaniem środków antykoncepcyjnych nie mają już swego usprawiedliwienia $\mathrm{w}$ dogmatach czy doktrynie, ale w tym, że "prawdziwy wierzący” będzie się do nich stosował. Pomaga to odróżnić się od innych, właśnie poprzez „praktykowanie cnoty, której nie wymaga żadna rozsądna moralność, lecz która służy umocnieniu jedności Kościoła pojmowanego prawie jak armia, w której niecałkowicie oddani żołnierze nie są w ogóle dopuszczani do służby" ${ }^{56}$. Moralność chrześcijańska zatem mimo braku fundamentu, jakim były dogmaty, utrzymuje się jako element historycznej tradycji Kościoła. Wszyscy wierzący bowiem, jak twierdzi Vattimo, zdają sobie sprawę z (możliwej) absurdalności niektórych wymogów Kościoła (skierowanych także wobec kapłaństwa kobiet czy osób homoseksualnych).

Należy zaznaczyć, że Vattimo nie ma na celu pokazania „niedzisiejszego” charakteru moralności chrześcijańskiej i w gruncie rzeczy jej krytyki, lecz docenia w pełni jej rolę. Nie traktuje jej jednak całościowo. Głównym bowiem pojęciem, nad którym podejmuje refleksję jest kategoria miłości i związane z nią przykazanie sformułowane przez kenotycznego Jezusa. Dla włoskiego myśliciela idea miłości zawarta w chrześcijaństwie i jej praktyczne konsekwencje stanowią właściwą istotę religii ${ }^{57}$. Natomiast wiele innych kwestii związanych z moralnością w chrześcijaństwie rozumie Vattimo jako „dziwne” czy nie mające już zbyt dużej wartości, tak jak jest to np. w przypadku moralności związanej życiem seksualnym. Na bardzo ogólnym poziomie miłości bliźniego oraz wartości takich jak: solidarność, miłosierdzie, potępienie rasizmu czy wojny, moralność chrześcijańska jest, wedle Vattima, istotna ${ }^{58}$. Wchodząc natomiast w szczegóły, widać, że wymaga ona nieco dystansu.

Jeśli zatem zależy nam na chrześcijaństwie, które pozbywa się swojego „naturalnego sacrum”, które rezygnuje z metafizycznego pojęcia Boga i mocnych struktur, lecz w którym pozostają wartości i moralność, to sekularyzacja jak najbardziej przybliża nas do tego obrazu religii ${ }^{59}$.

\footnotetext{
56 G. Vattimo, Belief, dz. cyt., s. 56.

57 Por. np. G. Vattimo, Poza interpretacja. Znaczenie hermeneutyki dla filozofii, tłum. K. Kasia, Universitas, Kraków 2011, s. 64.

58 G. Vattimo, Belief, dz. cyt., s. 56.

59 Por. Vattimo, After onto-theology..., dz. cyt., s. 35.
} 


\section{Laicyzacja jako droga do pełnego chrześcijaństwa}

Teoria sekularyzacji Gianniego Vattima jest teorią społeczną. Wymiar polityczny nie pojawia się tak wyraźnie jak społeczny i nie stanowi również dla włoskiego myśliciela sedna problemu związanego z religią we współczesności. Jak jednak przedstawiałaby się jego teoria sekularyzacji na płaszczyźnie politycznej? Czy po zmianie sekularyzacji na laicyzację nadal będzie ona mogła prowadzić do pełni chrześcijaństwa, którą określiliśmy wcześniej? Można by spytać jeszcze: dlaczego w ogóle warto rozważać ten problem, skoro świadomie nie pojawia się on u Vattima? Wydaje się jednak, że jest on istotny szczególnie ze względu na swoje praktyczne konsekwencje dotyczące polityki państwowej ${ }^{60}$. Również Richard Rorty dostrzega wagę tego problemu i krótko pokazuje, jak koncepcja Vattima łączy się $\mathrm{w}$ pewnych aspektach $\mathrm{z}$ jego własną, która z kolei dotyczy laicyzacji (sekularyzacji politycznej). W ramach laicyzacji zaś skupimy się głównie na jednym z postulatów instytucjonalnych (wyróżnionych przez Taylora) - postulacie separacji państwa od religii ${ }^{61}$. Pozostałe bowiem (tj. postulat neutralności państwa wobec religii oraz postulat równości w wolności sumienia) zarówno nie są w tym kontekście aż tak istotne, jak i częściowo łączą się z omawianym postulatem. Laicyzm zatem będziemy rozumieć wąsko - jako oddzielenie państwa od religii, innymi słowy: prywatyzację religii.

Rorty ${ }^{62}$ stwierdza, że jednym z głównych dążeń Vattima jest usunięcie zarówno Boga, jak i religii ze sfery epistemologicznej, co pomaga uniknąć konfliktu z nauką, który toczy się od wieków ${ }^{63}$. Religia porzuca swoje roszczenia do ja-

60 Filozofia Vattima jest szczególnie skupiona na praktycznym wymiarze filozofii takim jak etyka czy polityka. Sam Vattimo był czynnym uczestnikiem europejskiej sceny politycznej poprzez mandat w Parlamencie Europejskim. Dlatego właśnie wydaje mi się istotnym zbadać polityczny wymiar sekularyzacji, o której pisze włoski filozof.

61 Ponieważ zaś Rorty mógłby być zakwalifikowany przez Taylora jako zwolennik republikańskiego modelu sekularyzacji politycznej, to właśnie taki model będę tu rozważać. Por. Ch. Taylor, J. Maclure, dz. cyt., s. 34 .

62 O religii i sferach publicznej oraz prywatnej u Rorty'ego zob. np. E. Dann, Philosophy, Religion and Religious Belief after Rorty, w: R. Rorty, An Ehics for Today, Columbia UP, New York 2011.

63 Vattimo jednak widzi inne rozwiązanie tego problemu niż Rorty (usunięcie religii ze sfery publicznej czy sfery poznania) - wskazując na nieobiektywny charakter prawdy zarówno w przypadku religii, jak i nauki (oraz w ogóle wszystkiego, co w jakiś sposób opisuje świat). Opis świata proponowany przez religię i opis prezentowany przez naukę nie wchodzą ze sobą w konflikt, ponieważ stanowią oddzielne paradygmaty, interpretacje nie pretendujące do odzwierciedlania prawdy obiektywnej. 
kiejkolwiek prawdziwości, nie chce również badać rzeczywistości i wypowiadać o niej sądów, które miałyby mieć jakąś aksjologię i zatem konkurować z nauką o to, która lepiej czy prawdziwiej wyjaśnia rzeczywistość. Mówiąc krótko: „nie ma już sensu tak ostro przeciwstawiać sobie wiary i rozumu"64. W przypadku postulatu pozbawienia religii znaczenia poznawczego Rorty zauważa możliwość połączenia swojej teorii z koncepcją Vattima, ponieważ „sfera epistemiczna jest przestrzenią publiczną, przestrzenią, $\mathrm{z}$ której religia może i powinna się wycofać”65. Przy takim rozumieniu problem religii przenosi się z płaszczyzny społecznej na polityczną. Nie jest już istotne ludzkie nastawienie do religii jako takiej, lecz kwestia stosunku państwa, władzy politycznej do wierzących (a więc również do Kościoła). Rorty jednak prawdopodobnie myli te dwie płaszczyzny i utożsamia je ze sobą. Pisze bowiem:

Vattimo wydaje się mieć na celu właśnie taką sprywatyzowaną religię, kiedy opisuje sekularyzację kultury europejskiej jako spełnienie obietnicy wcielenia rozważanego jako kenosis, boskie oddanie nam wszystkiego. Zachód im bardziej jest zsekularyzowany, tym mniej hierokratyczny się staje, tym lepiej wypełnia obietnicę ewangelii, że Bóg nie będzie miał nas za swe sługi, ale za przyjaciół ${ }^{66}$.

Rorty sam używa słowa „kultura”, co już wskazuje bardziej na kontekst społeczny niż polityczny, w innym wypadku należałoby powiedzieć zamiast tego: „państw europejskich”. Aby jednak dobrze ukazać, czy Rorty faktycznie się myli, należy zbadać możliwość pełni chrześcijaństwa na gruncie laickiej koncepcji sekularyzacji.

Teoria Vattima opisująca pełnię chrześcijaństwa zwraca uwagę przede wszystkim na wartości i moralność obecne w tej religii. To one są jej sednem i to one również powinny stanowić to, co zostanie z religii po procesie sekularyzacji. Moralność jednak odwołuje się do relacji międzyludzkich i nie może raczej zostać sprywatyzowana. Wydaje się, że jedyną możliwą religią prywatną jest taka, która skupia się głównie na relacji człowieka z Bogiem, kontemplacji, modlitwie itd. Religia wedle Vattima taka nie jest. Prywatyzacja chrześcijaństwa, w którym najważniejsza jest moralność, doprowadziłaby do jego śmierci, tak jak wcześniej

\footnotetext{
64 G. Vattimo, Belief, dz. cyt., s. 87.

65 R. Rorty, G. Vattimo, dz. cyt., s. 36.

66 Tamże, s. 38.
} 
umarł Bóg metafizyki. Oczywiście same wartości wynikające z chrześcijaństwa by nie zanikły, ponieważ nadal mogłaby być obecna solidarność, miłość itd. Jednak nikt nie mógłby powiedzieć, że czyni tak a tak, ponieważ wyznaje wartości chrześcijańskie, albo dlatego, że zwyczajnie jest chrześcijaninem. Powodowałoby to zjawisko, które Rorty nazywa „przerywaczem-konwersacji” ${ }^{67}$ - gdy powie się, że zajmuje się jakieś stanowisko ze względów religijnych, dyskusja się kończy. Amerykański neopragmatysta przyznaje, że religia (usunięta ze sfery epistemologicznej) to coś, co przynależy nie tylko do szeroko pojętej sferze prywatnej, ale wręcz do samotności - „religia, która nie uważa kwestii ateizmu-teizmu za interesującą, może być tym, co pasuje twojej samotności”68. Rorty jednak podaje, że jest to również stanowisko Vattima, co nie jest zgodnie z tym, co przedstawiliśmy. Wydaje się zatem, że koncepcja laicka nie prowadzi do pełnej realizacji chrześcijaństwa, tak jak ma to miejsce w przypadku sekularyzacji, oraz że Rorty, opisując teorię Vattima, nie dostrzega ważnego rozróżnienia na sekularyzm i laicyzm ${ }^{69}$.

Sekularyzacja pojęta społecznie jako konflikt wartości może, czy wręcz musi, prowadzić do pełniejszej realizacji prawdy chrześcijaństwa, którą jest miłość. $\mathrm{Na}$ gruncie tej koncepcji filozofowie przyczyniający się do „odczarowania” świata, demaskowania i demitologizowania go, stają się orędownikami dobrej nowiny niesionej przez Jezusa. Nietzsche, Freud, Marks i inni wypełniają nieświadomie karty w księdze historii zbawienia zapoczątkowanej przez wcielonego Boga pozbawiającego się transcendencji. Teoria Vattima może zostać rozszerzona $\mathrm{w}$ taki sposób, że samo chrześcijaństwo jest również rozumiane jako sekularyzacja. Dzieje Jezusa bowiem ukazują, że sam Bóg jest demaskatorem i interpretatorem. Interpretacja jednak nie jest zakończona. Drugim, zaraz obok przykazania miłości, najważniejszym przesłaniem Jezusa jest interpretacyjny charakter wiary, Biblii czy samego Boga. Zadaniem wiernych zaś jest naśladować Zbawiciela w sensie moralnym - działać wedle przykazania miłości oraz znajdować właściwą dla siebie, w konkretnym czasie i miejscu, interpretację wiary. Ważne jednak jest to,

67 Por. R. Rorty, Philosophy and Social Hope, Penguin Books, New York 1999, s. 171.

68 R. Rorty, G. Vattimo, dz. cyt., s. 39.

69 Podobnie błędnie (w tym aspekcie) przedstawia myśl Vattima Zdzisława Kobylińska: „Autor Końca nowoczesności jest więc zwolennikiem sprywatyzowania religii”. Z. Kobylińska, dz. cyt., s. 68. Błąd ów oparty jest na myśleniu o prywatyzacji religii jako jedynie odseparowaniu Kościoła od państwa. Prywatyzacja jednak (przynajmniej w formie, w której rozumie ją Rorty) ma za zadanie wyrzucić religię jako taką ze sfery publicznej ze względu na jej „przerywający” charakter. W takim zaś sensie Vattimo na pewno nie jest zwolennikiem sprywatyzowania religii. 
aby pamiętać, że cały czas mówimy o sekularyzacji jako fenomenie społecznym wyrażającym nastroje ludzi i ich stosunek do wiary, nie zaś o laicyzacji (tj. sekularyzacji politycznej), która w przeciwieństwie do sekularyzacji nie prowadzi do pełni chrześcijaństwa. Spycha ona bowiem wartości i moralność chrześcijańską do sfery prywatnej.

\section{Bibliografia}

Artemiuk P., „Myśl słaba” Gianniego Vattimo a chrześcijaństwo, „Studia nad Rodziną" 2012, nr 16/1-2(30-31), s. 447-468.

Dann E., Philosophy, Religion and Religious Belief After Rorty, w: R. Rorty, An Ethics for Today, Columbia UP, New York 2011.

Girard R., Sacrum i przemoc, tłum. M. Plecińska, Wydawnictwo Brama, Poznań 1993.

Kobylińska Z., Gianniego Vattima postulat słabego chrześcijaństwa, „Seminare” 2016, t. 37, nr 3, s. 61-71.

Nietzsche F., Wiedza radosna, tłum. L. Staff, Warszawa 1906.

Otto R., Świętość, tłum. B. Kupis, Thesaurus Press, Wrocław 1993.

Rorty R., Philosophy and Social Hope, Penguin Book, New York 1999.

Rorty R., Vattimo, G., The Future of Religion, ed. by S. Zabala, Columbia UP, New York 2005.

Taylor Ch., Maclure J., Secularism and Freedom of Conscience, Harvard UP, Cambridge, MA 2011.

Taylor Ch., A Catholic Modernity, Oxford UP, New York-Oxford 1995.

Vattimo G., After onto-theology: philosophy between science and religion, w: Re-

ligion after Metaphysics, ed. M. Wrathall, Cambridge UP, Cambridge 2003.

Vattimo G., Belief, Stanford UP, Stanford 1999.

Vattimo G., Ślad śladu, tłum. E. Łukaszyk, w: J. Derrida, G. Vattimo, Religia, Wydawnictwo KR, Warszawa 1999.

Vattimo G., Koniec nowoczesności, tłum. M. Surma-Gawłowska, Universitas, Kraków 2006.

Vattimo G., Społeczeństwo przejrzyste, tłum. M. Kamińska, Wydawnictwo Naukowe Dolnośląskiej Szkoły Wyższej Edukacji, Wrocław 2006. 
Vattimo G., Poza interpretacją. Znaczenie hermeneutyki dla filozofii, tłum. K. Kasia, Universitas, Kraków 2011.

Vattimo G., Paterlini P., Nie być Bogiem. Autobiografia na cztery ręce, tłum.

K. Kasia, Wydawnictwo Krytyki Politycznej, Warszawa 2011.

Węcławski T., Wspólny świat religii, Znak, Kraków 1995.

\section{Streszczenie}

W artykule przedstawiono elementy filozofii religii włoskiego filozofa Gainniego Vattima skupione wokół zagadnienia sekularyzacji i jej relacji z chrześcijaństwem lub przynajmniej z pewną interpretacją tej religii. Refleksję nad desakralizacją świata przedstawioną $\mathrm{w}$ myśli Vattima ujęto w ramy klasyfikacji sekularyzacji dokonanej przez Taylora i Węcławskiego, a następnie zestawiono z koncepcją Rorty'ego, który twierdzi, że jego pogląd jest podobny do przedstawianego przez Vattima. Nie ma jednak wystarczających podstaw, aby przychylać się do tezy Rorty'ego.

Słowa kluczowe: Vattimo, sekularyzacja, chrześcijaństwo, religia, hermeneutyka

\section{Summary}

\section{Secularization as a Path to Full Christianity in the Light of Gianni Vattimo's Concept}

A part of the Italian philosopher Gianni Vattimo's philosophy of religion, focused on the question of secularization and its relation to Christianity or at least to some interpretation of this religion, is presented in the article. The concept of desacralizing the world which is present in Vattimo's thought is considered on the grounds of Taylor's and Węcławski's classification of secularization, and then compared with Rorty's concept, which claims to be similar to Vattimo's. However, there is no sufficient base on which one could support Rorty's thesis.

Key words: Vattimo, secularization, Christianity, religion, hermeneutics 